\title{
The Optimism of the Heart
}

\section{JOHN BELLAMY FOSTER}

The following intellectual biography of Harry Magdoff is a slightly revised and expanded version of a piece that was posted on MRzine a few days after Harry's death on January 1, 2006. It evolved out of an earlier biography I wrote for the Biographical Dictionary of Dissenting Economists in 2000. Since the aim of this biography was to present the basic facts of Harry's intellectual career, personal feelings and observations were largely excluded. A brief word on Harry's character and the warm emotions he engendered within those who knew him therefore seems essential here.

I met Harry in 1981 when I first visited the MR office in New York. Paul and I had met and corresponded at length already. But I was completely unprepared for the comradeship with which Harry (and Beadie) greeted me. We were friends from the moment we met. In that very first encounter I was overwhelmed, as I would be in all the years that followed, by Harry's kindness and humanity along with his deep well-springs of wisdom. Even now I look back on that day in wonder.

For decades after our first meeting I was lucky to be able to work with both Harry and Paul in various capacities (usually at a distance, separated as we were geographically). In 2000 Bob McChesney and I joined Harry and Paul as coeditors of MR. In these last years I got to know Harry in somewhat different ways as we took on the challenges of socialism in the twenty-first century. No mere words can describe the degree of courage and commitment that Harry inspired through such close collaboration. Harry was completely devoted to MR and was immensely pleased that at the end of his life, as he put it, "the MR flag is still flying." Once during his last year, as signs appeared of his failing, I tried to tell Harry that I loved him. He simply passed it off, as if it was a point that had been settled long ago between us-as it had. I will miss him always.-JBF

Harry Magdoff was born on August 21, 1913, in the Bronx, New York, the son of working-class Russian Jewish immigrants. His father worked as a housepainter; his mother worked as a housewife and for a brief time helped run a hole-in-the-wall candy store. He grew up in a New York immigrant community at a time when war and revolution were common topics of conversation. On one occasion, he overheard a debate in a local 
park in which it was pointed out that Britain "owned" India. He was shocked that one country could own another and began to explore the history of colonialism. In 1929, at the age of fifteen, he encountered Karl Marx for the first time, when he found a copy of Contribution to a Critique of Political Economy in a used bookstore. Reading the famous preface, he was stunned. "It blew my mind," he was to recall. Marx's "view of history was a revelation. I didn't understand the rest of the book, which cost me a quarter, but that got me started reading about economics. We were going into the Depression then and I wanted to figure out what it all meant" (Green, 2003). The "determining element" in his emerging radicalism, however, was what he witnessed at the demonstration of the unemployed in Union Square in March 1930:

The fact that I went there shows an inclination, an interest. The experience, however, was overwhelming. The square was mobbed, crowded with gaunt-faced people, dressed as you might expect people in poverty to dress. They listened quietly to the speeches, applauding and shouting from time to time. Then a speaker roused the crowd to a high pitch and urged that all march down to City Hall. As the crowd began to move, mounted police appeared. With billy clubs, they beat anyone within reach ruthlessly on heads, arms, shoulders. Blood splattered. I ran like hell. (Phelps, 1999)

While at the City College of New York, where he commenced studies of engineering, physics, and mathematics, Magdoff supported himself by teaching courses on Marxism in Yiddish to working-class men and women in Newark, Elizabeth, and New Brunswick, New Jersey. At City College, he was active in a progressive student organization known as the Social Problems Club and became editor of Frontiers, the club's monthly magazine. In 1932, he visited Chicago to participate in the founding conventions of the National Students League and the Youth League Against War and Fascism. During that trip, he married his fellow New York student Beatrice Greizer. Beadie (as her friends called her) also grew up in the Bronx and had been marching on picket lines ever since she was a pre-schooler, along with her pro-union mother. When they first met, some four years before, Harry and Beadie, together with other friends, would climb on her tenement house roof, listen to classical music, and discuss art, as part of a neighborhood group dubbed Friends of Culture. They remained together and engaged in a common struggle for humanity until Beadie's death nearly seventy years later.

Magdoff became editor (along with the celebrated poet, Muriel Rukeyser) of the National Students League's national publication 
Student Review in 1932-33. In one of the issues in 1932, he wrote (foreshadowing his later views): "Very often, particularly in the classroom, imperialism is defined as the policy of a government aimed at conquering or controlling foreign territories.... In its attempt to be all-inclusive, to take in all attempts at foreign conquest, this definition excludes the key to the understanding of each. It covers everything but explains nothing. There is a difference between the colonial annexation by highly developed monopoly capitalism searching for markets and raw materials, and the colonial projects of slaveholding Rome."

He was twice ousted from City College for his political activitiesat first suspended and then expelled-and went on to New York University's School of Commerce, from which he received a BS in economics in 1936.

Upon graduation from New York University, Magdoff joined the National Commission on Technological Unemployment and Reemployment of the Works Progress Administration, based in Philadelphia. His salary wasn't high enough at first for Beadie to give up her teaching position in New York so he commuted for a time. He headed a project directed at developing detailed productivity measures for a number of manufacturing industries. While working for this project, Magdoff developed the method for measuring productivity in individual manufacturing industries still used by the Department of Labor. The results of this research were published in 1939 in a book-length government report, Production, Employment, and Productivity in 59 Manufacturing Industries, 1919-1936 (1939a). Magdoff also published two related landmark articles on the development of productivity measures and the growth of the services sector (see 1939b and 1940).

Following the completion of the WPA project, he took up a position with the National Defense and Advisory Board in Washington, D.C., where he was put in charge of the Civilian Requirements Division, which, together with the Military Requirements Division, studied industrial capacity and productivity with the purpose of discerning bottlenecks that might emerge in the event of full capacity production during wartime. "Another group," Magdoff recalled, "was studying the military angle. We felt they were underestimating things. Six fellow employees and I wrote a memorandum about this because it was clear the Army's methods were outmoded. We were like Young Turks. Our memorandum reached Roosevelt's desk on the day Pearl Harbor was attacked" (Green, 2003).

Magdoff was soon asked to sit on the War Production Board monitoring the industrial effort. He was appointed program progress officer in 
charge of the WPB-732 monthly statistical series on metalworking industries, which assessed the productive capacity in these industries. In this capacity he also inspected and was involved in the planning and control of factories producing machinery and equipment for metal-working factories-for example, manufactures of machine tools, foundry equipment, ball bearings, grinding wheels, chains, and so on. (Some of the lessons that he drew from this experience were to be addressed in his later work, for example, "Creating a Just Society: Lessons from Planning in the U.S.S.R and the U.S." [2002b].)

In 1944, as the war came to a close, Magdoff became the chief economist in charge of the Commerce Department's Current Business Analysis Division. He was responsible for overseeing the publication of the Survey of Current Business, for which he authored the introduction in 1946. His duties also included writing a weekly report on the economy for cabinet meetings and preparing other analyses of economic developments.

Secretary of Commerce (and former vice president) Henry A. Wallace requested that Magdoff become his special assistant in 1946. He accepted the position reluctantly, not wishing to serve as a general economic advisor and preferring his role as chief economist at Commerce. He was given the job of overseeing the work of the Bureau of Standards and of the Census. He also authored weekly economic position papers for Wallace for cabinet meetings with President Truman.

From mid-1947 until around 1952, Magdoff worked as program director for the New Council of American Business, a pro-New Deal business group. In addition to directing their program, he authored monthly newsletters and position papers, gave talks on the economy, and prepared congressional testimony. He also met on occasion with Henry Wallace in this period, answering Wallace's questions on economics and foreign policy in connection with the latter's 1948 bid for the presidency on the Progressive Party ticket. Magdoff authored Wallace's small-business platform.

This time was the beginning of what came to be known as McCarthyism. Following his departure from the New Council, Magdoff suddenly found employment opportunities in government and policy analysis closed off to him. He was compelled to testify to congressional committees and grand juries on his political background and subjected to continual harassment from the FBI. Effectively blacklisted, he left Washington with his family (Harry and Beadie now had two sons, Michael and Fred) and moved to New York where he could seek 
employment in business. Beadie resumed teaching. In New York, the persecution continued. On one occasion when Magdoff was called to testify before a Senate committee, the news appeared on the front page of the New York Times. The landlord would not renew the lease on their apartment and the family was forced to move.

For almost a decade, out of economic necessity, he worked on Wall Street as a financial analyst and stockbroker. He eventually took a job as a financial analyst for an insurance company, occasionally advising labor unions on pension fund investments. Together with Beadie he also sold insurance, mainly to other radicals. In the late 1950s, he joined Russell and Russell, a publisher of out-of-print scholarly books, among them W. E. B. Du Bois's Black Reconstruction in America. He subsequently became co-owner of the firm. He remained at Russell and Russell until 1965, when the publishing house was bought by Atheneum.

During the late 1950s and early 1960s, Magdoff taught classes for a number of business firms, in response to the requests from a group of pro-New Deal businessmen. After the president of the New School for Social Research heard about these sessions, Magdoff was invited to teach at that institution as an adjunct, which he did throughout the 1960s; he also taught at Yale for one semester on a similar basis. His courses included the economics of planning, economic development, the history of economic thought, the structure of U.S. business, imperialism, and Marxian economics.

After leaving Russell and Russell, upon its purchase by Atheneum in 1965, Magdoff was at last free, due to a modicum of financial independence obtained through the sale of his interest in the company, to pursue his intellectual and political interests as he saw fit. Although he dreamed at one point of going to Cambridge in England or some other like location and engaging in a "life of study," he chose instead the harder course of complete devotion to the cause. He reemerged in print as a public Marxist intellectual with a number of works in 1965 including "Problems of United States Capitalism" in The Socialist Register. A section of that article that was to prove prescient was entitled "The Economy Grows on Credit." Here he explained how the U.S. economy had increasingly become dependent on the expansion of credit/debt in order to stimulate demand. Aside from the dangers of a financial collapse, this tended to raise the level of profits necessary for business, which required higher returns in order to repay the debt plus interest. "In a semistagnant economy" already characterized by a slackening of capital formation, he observed, "larger profits cannot come from greater accumulation of cap- 
ital but by reducing the share going to wages and salaries." Yet, wage and salary earners needed to increase their incomes steadily as well, since they too were caught in the debt trap. The share of consumer income that went toward repaying debts, he noted, was 14 percent in 1951, rising to 21 percent by 1963.

Magdoff had been an avid reader of Monthly Review: An Independent Socialist Magazine, edited by Leo Huberman and Paul Sweezy, from its very first issue. He found it on a newsstand on 42nd Street near the library and immediately "fell in love with it for three reasons: it talked about socialism, a taboo topic at the time; it declared itself independent, beyond the control of any party; and the language was clear and simple. These things gave it a quality that was altogether different." He became close friends with Paul Baran, professor of economics at Stanford and a mainstay of Monthly Review, and MR editors Sweezy and Huberman. In March 1965, he wrote his first article for the magazine, "The Achievement of Paul Baran," in a memorial issue devoted to Baran. In the same year, he presented a talk on "The American Empire and the U.S. Economy" at the second Socialist Scholars Conference in New York. This was revised to become the closing chapter of his book The Age of Imperialism: The Economics of U.S. Foreign Policy (1969). The main body of The Age of Imperialism, chapters 2-5, was first presented in a preliminary form at the third Socialist Scholars Conference in 1967. The Age of Imperialism was to have an immense impact on the U.S. left in the context of the struggle against the Vietnam War and was translated into fifteen languages. It was to become-along with Baran's Political Economy of Growth (1952), Baran and Sweezy's Monopoly Capital (1966), and Harry Braverman's Labor and Monopoly Capital (1974)—one of the primary works to define the Monthly Review tradition of U.S. political economy.

Magdoff's book had as its object nothing less than the rediscovery of U.S. imperialism. It demonstrated that the United States had an empire, although one different from the empires of Britain and France that had preceded it, and that this (even more than the contest with the Soviet Union) was the context in which the Vietnam War had to be understood. Addressing what was widely viewed as an anomaly in the United States in its relation to the rest of the world, arising from the existence of an interventionist foreign policy accompanied by a seemingly "isolationist economy," Magdoff showed that the U.S. economy was in fact anything but isolationist. Here, he emphasized the flow of foreign direct investment abroad and its effect of creating a cumulative stock of investment, generating a return flow of earnings. He criticized the common error of 
simply comparing exports or foreign investments of multinational corporations to GNP. Rather, the importance of these economic flows could only be gauged by relating them to strategic sectors of the economy, such as the capital goods industries; or by comparing the earnings on foreign investment to the profits of domestic nonfinancial business.

In this connection, Magdoff provided data showing that earnings on foreign investments had risen from about 10 percent of all after-tax profits for U.S. domestic nonfinancial corporations in 1950, to around 22 percent in 1964. These startling numbers drew a lot of attention, and prominent academics (Robert W. Tucker and Benjamin Cohen) alleged that Magdoff's calculations were invalid since, they claimed, he had made two errors: (1) including profits from financial corporations in his figures for profits from foreign investment, while excluding financial corporations from the data on domestic corporations; (2) using figures for profits on foreign investment that were before taxes, while employing data for profits on domestic corporations that were after taxes. In response to these criticisms Magdoff wrote a "Technical Note" for his 1978 book Imperialism: From the Colonial Age to the Present in which he showed that both criticisms were based on lack of familiarity on the part of the critics with government statistics and statistical techniques. He explained not only that he had taken account of the earnings of financial corporations in his calculations of both profits on foreign investment and returns to domestic corporations, but that his results had been confirmed (to within less than a percentage point-well below the margin of error in the basic data) by more complete government statistics (in which the earnings on foreign investment of nonfinancial and financial corporations were for the first time separated) published a few years later. With respect to his treatment of taxes, not only did he not make the error of comparing profits before taxes to profits after taxes-his calculations were all based on after-tax figures-but, ironically, it was the critics who, due to their lack of familiarity with government data, ended up making this mistake, not realizing that what they simply assumed were before taxes figures were actually after taxes. "The shoe, then," he wrote, "is on the other foot. It is Professors Tucker and Cohen who, in their eagerness to expose alleged falsifications of data by radicals, fall into the noncomparability trap."

The Age of Imperialism was also notable for its arguments on international financial expansion of U.S. capital, based on the dollar's hegemonic position in the world economy and on the growth of a debt trap in the third world. It was here that Magdoff first explained the "reverse 
flow process" inherent in the continuous reliance on foreign debt-an issue to which he was to return in 1984 in his article "The Two Faces of Third World Debt." Assuming the simple case of an annual loan of $\$ 1000$ at 5 percent interest "to be repaid in equal installments over 20 years," it follows that, in the fifth year, almost fifty percent of the annual loan will go to servicing the debt; in the tenth year, nearly 90 percent of the loan will be devoted to debt service; in the fifteenth year, the outflow for interest and amortization will be greater than the loan itself; and, in the twentieth year, "the borrower is paying out more than $\$ 1.50$ on past debt for every $\$ 1.00$ of new money he borrows."

Would it be possible, Magdoff asked, for a country to avoid this trap by not borrowing year after year, but instead using the borrowed money to develop industry to provide the revenue to dispense with borrowing and even pay off the debt? Here it needed to be understood that, since the repayment had to be made in the currency of the creditor nation, the debt could only be repaid (irrespective of the rate of growth) if there were enough exports to provide the needed foreign exchange. As early as the late 1960s in The Age of Imperialism, long before the third world debt problem was deemed critical, Magdoff observed that "the service payments on the debt of the underdeveloped world has increased more rapidly than has the growth in its exports. Hence the burden of debt has become more oppressive and the financial dependency on the leading industrial nations and their international organizations such as the World Bank and the International Monetary Fund has increased accordingly."

The essence of the new stage of imperialism represented by the United States was the globalization of monopoly capital under conditions of U.S. hegemony. Magdoff wrote in the closing pages of The Age of Imperialism:

The typical international business firm is no longer limited to the giant oil company. It is as likely to be a General Motors or a General Electricwith 15 to 20 percent of its operations involved in foreign business, and exercising all efforts to increase this share. It is the professed goal of these international firms to obtain the lowest unit production costs on a worldwide basis. It is also their aim, though not necessarily openly stated, to come out on top in the merger movement in the European Common Market and to control as large a share of the world market as they do of the United States market.

Not only were these trends with respect to the growth of monopoly capital borne out in the decades that followed, but they were to culmi- 
nate in the United States in the late 1990s and early 2000s in the greatest merger wave since the beginning of the twentieth century (see Du Boff and Herman, 2001) - one no longer aimed at control of national markets, but at the control of as large a share as possible of the world market.

The introduction to The Age of Imperialism had concluded with these words: "Students frequently put the question: is imperialism necessary? The point I am trying to make here... is that such a question is off the mark. Imperialism is not a matter of choice for a capitalist society; it is the way of life of such a society." Nevertheless, questions about the larger history and theory of imperialism and its relation to the growth of capitalism naturally arose, and Magdoff found himself giving many talks and writing numerous essays over the 1970s directed at answering these questions-which were later brought together in Imperialism: From the Colonial Age to the Present (1978).

The lead essay in this volume was entitled "European Expansion since 1763" and dealt with the history of imperialism from the late-eighteenth century to the 1970s. It was originally published in volume 4 of the fifteenth edition (1974) of the Encyclopedia Britannica as the second section of the Macropedia article on "Colonialism (c.145O-c.1970)." Magdoff's analysis was notable for its treatment of both the main historical developments up through the Vietnam War and its discussion of the theoretical literature-particularly the interpretations of the "new imperialism" developed by Hobson, Lenin, and Schumpeter. (In its 1979 edition, the Britannica, succumbing to political pressure, lopped off Magdoff's article at 1914, substituting a conservative Cold War ideological account by Berkeley professor Richard Webster that in the name of "updating" dropped all mention of the U.S. role in Vietnam in 1954-73-previously included in Magdoff's treatment-ending the analysis instead with the defeat of the French in Vietnam in 1954 [see Franklin, 1982].)

Most of the other essays in Imperialism dealt directly with misconceptions about the history of imperialism. Of key importance was Magdoff's response once again to the question: "Is Imperialism Really Necessary?" In answer to the common contention that capitalism and imperialism were two entirely separate realities, and that the latter was not necessarily an attribute of the former, he argued that capitalism had been from the start a world system and that imperialist expansion in the broad sense was just as much a part of that system as the search for profits itself. He also argued against those on the left who sought to generate an analysis of modern imperialism through a particular theory of economic crisis, or from the necessity for the export of capital, rather than 
recognizing that imperialism was intrinsic to capitalism's globalizing tendencies from the very start. Any simple, mechanical, purely economic explanation for imperialism was to be avoided-rather the sources of modern imperialism were to be found in the historical development of capitalism since the sixteenth century. "The elimination of imperialism," Magdoff concluded, "requires the overthrow of capitalism."

In May 1969, Magdoff joined Paul Sweezy as coeditor of Monthly Review, replacing Leo Huberman who died in 1968. His new role as a coeditor of the leading independent socialist magazine in the United States, which also had a strong world presence, allowed him to play a wider role in the nurturing of a new generation of radicals that had developed with the New Left. In the 1960s and '70s, he traveled extensively abroad (usually with Beadie) - to Europe, Mexico, Japan, India, Israel, Venezuela, Egypt, and elsewhere. As Harry was to recall, "We made nice friendships with presidents, heads of government." Everywhere there was interest in the analysis of Monthly Review. As in the case of Paul Sweezy and Paul Baran, he struck up a friendship in Cuba with Che Guevara. His memories of Che (originally in the form of a letter to a friend) were later published as "Encounters with Che" (2004c). Che and Harry had long talks on economics and planning on a couple of occasions in Cuba and New York. Referring to what was to be their final meeting, Magdoff wrote: "I have my portion of vanity, which pushes me to report our parting words. Recognizing that he was a nice friendly fellow, I asked, 'You know how I feel about Cuba. What should I do?' Che answered, 'Keep on educating me."”

Over the course of the 1970s and '80s, Magdoff and Sweezy collaborated in a series of articles that constituted a running commentary on the U.S. economy and its global role, resulting in five essay collections entitled The Dynamics of U.S. Capitalism (1972), The End of Prosperity (1977), The Deepening Crisis of U.S. Capitalism (1981), Stagnation and the Financial Explosion (1987), and The Irreversible Crisis (1988). One key essay was "Banks Skating on Thin Ice" in February 1975 (later reprinted in The End of Prosperity) in which Magdoff and Sweezy highlighted the extent of the financial contradictions of capitalism. Not only did these works extend the analytical models of Baran and Sweezy's Monopoly Capital and Magdoff's The Age of Imperialism, but the analysis was deepened and widened to take into account the financial explosion and the questions of productivity, investment, savings, inflation, unemployment, the decline of U.S. hegemony, and the resurfacing of economic stagnation. 
Together with Sweezy, Magdoff displayed an economic approach that brought together and synthesized the insights of Marx, Luxemburg, Kalecki, Hansen, and Schumpeter. Even more than Sweezy, Magdoff was to emphasize that stagnation was an endemic tendency of capitalism, not confined simply to its monopoly stage (see his "International Economic Distress and the Third World," MR, April 1982-reprinted in this issue). His deft handling of economic statistics gave Monthly Review's political economy clarity and an empirical grounding almost entirely lacking in other left publications. In 1979 and 1980, he authored (together with Sweezy) two key essays on productivity statistics and the understanding of economic growth and crisis- "Productivity Slowdown: A False Alarm" and "The Uses and Abuses of Measuring Productivity" (reprinted in 1981 in The Deepening Crisis of U.S. Capitalism). Here he employed the knowledge that he had developed in the formulation of the techniques for measuring productivity in the 1930s, to explain common mistakes in economic interpretation arising from a failure to understand the meaning and limitations of productivity data.

In 1992 he authored a lengthy essay for the Socialist Register, entitled "Globalization-To What End?" Providing a long historical view of globalization, Magdoff argued against the common view that "a new 'international' of capital [was emerging] that will make and enforce the rules of international relations." It was true that attempts were being made to strengthen international institutions in the face of the globalization of finance and other developments. But behind all of these structures lay nation-states and their intense competition with one another, which, rather than letting up, showed signs of intensifying. New sources of tension, disharmony, and international rivalry were thus emerging even among those nations at the core of the capitalist system. At the same time, the globalization of monopoly capitalism was manifested in a widening of "the overall gap between core and periphery nations."

Magdoff's empirical analysis of globalization emphasized the dramatic shift in the nature of U.S. foreign direct investment from an early preponderance of manufacturing investment to the later dominance of finance, with the latter exceeding the former by a third by 1990. Most important was his description of the overall worsening relative economic position of countries in the periphery over the 1980s (excluding the "four tigers": South Korea, Taiwan, Singapore, and Hong Kong)-with rapid increases in their long-term debt made worse due to a decline in their share of world exports.

In the face of economic stagnation in the Soviet Union and the devel- 
opment of economic restructuring strategies during the perestroika period under Gorbachev, Magdoff, together with Sweezy, wrote in spring 1990 a two-part assessment of "Perestroika and the Future of Socialism." They argued that the failures of Soviet planning and the emergence of stagnation were not inherent failures attributable to central economic planning itself, but were traceable to the peculiarities of Soviet development. In particular, they emphasized that the Soviet Union had developed as a sui generis war economy that relied on the forced drafting of labor and raw materials-a form of development that was necessarily self-limiting over the long term. Further, the Soviet worship of growth rates and its competition with the United States had led to an overemphasis on production and investment in heavy industry in relation to consumption. These factors were further complicated by enormous waste and inefficiency in the use of material inputs and failure to maintain and replace existing plant and equipment. Finally, the Soviet reliance on extreme bureaucratization, resulting from the conditions under which central planning and massive industrialization had been introduced under Stalin-who forcibly rejected the more cautious approach advanced by Bukharin-itself contributed to the overall stagnation and made reform of the system difficult.

The biggest mistake that could be made in the perestroika process, they argued, would be to assume that the principle of central planning itself (not to be confused with economic commandism) was at fault under these circumstances, and to turn uncritically to the market. Markets generally were utilized for three tasks: (l) distribution of goods and services to consumers, (2) allocation of productive resources and investment between sectors; and (3) the determination of how much individuals and groups get paid for their labor and other assets they may own. Central economic planning relied on the market for the first of these tasks. It would be fatal to a socialist economy, they argued, to turn to the market as the principal means of solving the second and third. And any attempt to open the floodgates and integrate the much weaker Soviet-style economies with the stronger advanced capitalist economy would be disastrous for the former.

Magdoff's approach to the question of socialism and planning had always emphasized that the concrete historical conditions had to be addressed-there was no definite formula, rather methods of trial and error had to be applied in relation to changing historical circumstances. The biggest mistake of post-revolutionary societies such as the Soviet Union and China was to worship the mechanisms of planning and 
bureaucratization while failing to attend to the most pressing human needs (the addressing of which is the main virtue of planning). Socialism itself could never be separated from its basic aims, the first of which was "the elimination of human domination and exploitation of other humans." Such views on planning, egalitarianism, and democracy had been articulated by Magdoff many times over the years (see, for example, Magdoff, 198lb). His analysis of the building of a viable society was systematically advanced in his 2005 essay (written with his son Fred), "Approaching Socialism." Among other factors stressed in this article was the need to protect the natural environment.

In 2004 Magdoff (together with his MR coeditor John Bellamy Foster) coauthored a foreword to Martin Hart-Landsberg and Paul Burkett's China and Socialism (first published as a book-length special issue of Monthly Review in July-August 2004 and then as an actual book in the following year). In their forward Magdoff and Foster argued: "Once a post-revolutionary country starts down the path of capitalist development-especially when trying to attain very rapid growth-one step leads to another until all the harmful and destructive characteristics of the capitalist system finally reemerge. Rather than promising a new world of 'market socialism,' what distinguishes China today is the speed with which it has erased past egalitarian achievements and created gross inequalities and human and ecological destruction."

The critical thrust and all-encompassing nature of Magdoff's thought was well conveyed by his classic 1982 essay (reprinted in this issue), "The Meaning of Work: A Marxist Perspective." It opened with a critical consideration of Edward Bellamy's utopian conception of socialist society in Looking Backward, in which work viewed in a Smithian sense as a sacrifice was to be replaced as much as possible by leisure. The article closed by affirming William Morris's rejection of Bellamy's utopia in favor of a socialist vision (inspired by Marx), where work is seen not as a pain, but as an object in itself in its unalienated condition-energetic life activity devoted to useful and often pleasurable ends. In his wide-ranging argument he outlined the stages in the division of labor over the long course of human evolution, focusing on the separation of town and country, of head and hand (extending as far back as Ancient Greece), and on the degradation of labor under modern industry.

As a revolutionary thinker, Magdoff always raised the question of education as Marx himself had raised it: Who educates the educator? Often in his conversations and correspondence he would attempt to explain a complex issue by drawing on a particular, often humorous 
anecdote from his own wealth of experiences. These anecdotes were meant as simple memory devices: ways of encapsulating and holding on to important critical insights. They invariably expressed dialectical contradictions. Theory, as he explained in the introduction to Imperialism: From the Colonial Age to the Present, was never about watertight models, but about the kinds of real world problems and contradictions that defined particular historical epochs-and about the keys to revolutionary praxis under such conditions.

In the 1990s, Monthly Review went through a number of transformations. Finding it much more difficult to write and to carry out the onerous duties of editing in their eighties, Magdoff and Sweezy brought Marxist scholar Ellen Meiksins Wood on board as a coeditor, a role she fulfilled from March 1997 to March 2000. Beginning in April 2000, the magazine was edited by Magdoff and Sweezy, along with John Bellamy Foster and Robert W. McChesney, until Sweezy's death in February 2004 and McChesney's departure that June-leaving the magazine with just two coeditors-Magdoff and Foster-once again. Despite all of these changes, Monthly Review retained its identity as the world's leading independent socialist magazine.

After Beadie's death in June 2002, Magdoff relocated to Burlington, Vermont to live with his son Fred and his daughter-in-law Amy Demarest. In these years, a renewed outflowing came from his pen. Special issues on the economy in Monthly Review in four successive Aprils (2001, 2002, 2003, and 2004) were produced by Magdoff and his $M R$ coeditors (with the help of Fred Magdoff). In 2003, some of his earlier work on imperialism was brought together under the title Imperialism Without Colonies, and a conference on Imperialism Today was held in Burlington, Vermont in celebration of his ninetieth birthday, with speakers coming from as far away as India (in the case of the noted Indian economist Amiya Kumar Bagchi). The esteem with which he was held by the participants was summed up by U.S. Representative Bernie Sanders (Vermont-Ind.), who stated:

Recently, we have heard a great deal about America's greatest generation. Harry Magdoff is, along with many others in the Monthly Review community, the true heart of the greatest generation of Americans. He fought for the unemployed in the depression; he played a vital role in the war against fascism; he bravely endured when the right wing tried to destroy America's progressive voices.

When a generation of young Americans wanted to know how it was possible that the United States would make war on the distant nation of 
Vietnam, Harry taught them that imperialism, despite the end of the colonial period, still was a dominant force in the relations between nations. Always ready to articulate the needs of the poor, the outcast, and the deprived, Harry has been a pillar of support for those who believe that economic justice is worth fighting for. Harry's wisdom, his loyalty to the wretched of the earth, his constant courage in the face of tough times, have all provided an invaluable example for those of us in later generations. (Foster and McChesney, 2003)

In 2003-05, Magdoff wrote important essays with his son Fred on unemployment ("Disposable Workers") and socialism, and did major interviews on the world economy and planning-conducted by his friend Huck Gutman. His 2004 eulogy to Paul Sweezy, "Farewell, Comrade Paul," was a moving statement on their long intellectual partnership and the deep friendship that lay behind it.

In all of these works and in his life as a whole, Magdoff revealed a rare quality - the ability to combine the most searching intellectual inquiry, often involving ruthless criticism of existing institutions, with the deepest level of human compassion and understanding. He once stated (altering Gramsci's famous saying): "You have to be a pessimist of the mind, but an optimist of the heart" (Green, 2003). What always struck those who knew Harry Magdoff best was his prodigious "optimism of the heart"-the ultimate basis from which he derived his uncompromising socialist worldview. We will remember him.

\section{Harry Magdoff's Major Writings}

(1939a), Production, Employment, and Productivity in 59 Manufacturing Industries, 1919-1936 (coauthored with Irving H. Siegal and Milton B. Davis), Philadelphia: WPA National Research Project, May.

(1939b), "The Purpose and Method of Measuring Productivity," Journal of the American Statistical Association, 34, June, 308-18.

(1940), "The Service Industries in Relation to Employment Trends" (coauthored with David Weintraub), Econometrica, 8, October, 289-311.

(1969), The Age of Imperialism: The Economics of U.S. Foreign Policy, New York: Monthly Review Press.

(1970), Vietnam, the Endless War (coauthored with Leo Huberman and Paul M. Sweezy), New York: Monthly Review Press.

(1972), The Dynamics of U.S. Capitalism (coauthored with Paul M. Sweezy), New York: Monthly Review Press.

(1974), Revolution and Counter-Revolution in Chile (coauthored with Paul M. Sweezy), New York: Monthly Review Press.

(1977), The End of Prosperity (coauthored with Paul M. Sweezy), New York: Monthly Review Press.

(1978), Imperialism: From the Colonial Age to the Present, New York: Monthly Review Press. 
(1981a), The Deepening Crisis of U.S. Capitalism (coauthored with Paul M. Sweezy), New York: Monthly Review Press.

(1981b), "Socialism, Democracy, and Planning," Monthly Review, 33(2), June, 22-30.

(1982a), "International Economic Distress and the Third World," Monthly Review, 33, April, 1-13.

(1982b), "The Meaning of Work: A Marxist Perspective," Monthly Review, 34, October, 1-15.

(1987), Stagnation and the Financial Explosion (coauthored with Paul M. Sweezy), New York: Monthly Review Press.

(1988), The Irreversible Crisis (coauthored with Paul M. Sweezy), New York: Monthly Review Press.

(1990a), "Perestroika and the Future of Socialism-Part 1," (coauthored with Paul M. Sweezy), Monthly Review, 41, March, 1-13.

(1990b), "Perestroika and the Future of Socialism-Part 2," (coauthored with Paul M. Sweezy), Monthly Review, 41 (10), April, l-17.

(1992), "Globalization-To What End?," Socialist Register; 1992, London: Merlin Press.

(200la), "The New Economy: Myth and Reality" (coauthored with John Bellamy Foster and Robert W. McChesney-with the help of Fred Magdoff), Monthly Review, 52 (11), April, 1-15.

(200lb), "Paul Krugman vs. the Quebec Protestors" (coauthored with John Bellamy Foster and Robert W. McChesney), Monthly Review, 53 (2), June, 1-5.

(2002a), "Slow Growth, Excess Capital, and a Mountain of Debt" (coauthored with John Bellamy Foster and Robert W. McChesney-with the help of Fred Magdoff), Monthly Review, 53 (11), April, 1-14.

(2002b), "Creating a Just Society: Lessons from Planning in the U.S.S.R. \& the U.S." (interviewed by Huck Gutman), Monthly Review, 54 (5), October, 1-22.

(2003a), Imperialism Without Colonies, New York: Monthly Review Press.

(2003b), "What Recovery?" (coauthored with John Bellamy Foster and Robert W. McChesney-with the help of Fred Magdoff), Monthly Review, 54 (11), April, 1-13.

(2003c), "Capitalism as a World Economy: An Interview of Harry Magdoff” (interviewed by Huck Gutman), Monthly Review, 55 (4), September, 1-13.

(2004a), "Foreword" (coauthored with John Bellamy Foster), in Martin Hart-Landsberg and Paul Burkett, China and Socialism, special issue of Monthly Review, 56 (3), July-August, 2-6.

(2004b), “Disposable Workers" (coauthored with Fred Magdoff), Monthly Review, 55 (11), April, 18-35.

(2004c), "Encounters with Che," Monthly Review, 56 (4), September, 47-50.

(2004d), "Farewell, Comrade Paul," Monthly Review, 56 (5), October, 1-3.

(2005), "Approaching Socialism" (coauthored with Fred Magdoff), Monthly Review, 57 (3), July-August, 19-61.

\section{Other References}

Du Boff, Richard B. and Edward Herman (2001), "Mergers, Concentration, and the Erosion of Democracy," Monthly Review, 53(1), May, 14-29.

Editors (2002), "Remembering Beadie Magdoff," Monthly Review, 54 (5), October.

Foster, John Bellamy (1986), The Theory of Monopoly Capitalism, New York: Monthly Review Press. 
Foster, John Bellamy (2000), "Harry Magdoff (born 1913)," Biographical Dictionary of Dissenting Economists (Northampton, MA: Edward Elgar), 385-94.

Foster, John Bellamy (2002), "The Rediscovery of Imperialism," 54 (6), Monthly Review, November, 1-16.

Foster, John Bellamy and Robert W. McChesney (2003), "Notes from the Editors," Monthly Review, 55 (3), July-August, inside covers.

Franklin, Bruce (1982), "On the Rewriting of History," Monthly Review, 34, November, 40-47.

Green, Susan (2003), "The Sage of Imperialism," Seven Days (Burlington, Vermont), April 3, 2003.

Phelps, Christopher (1999), "An Interview with Harry Magdoff," Monthly Review, 51, May, 54-73.

Pool, John C. and Stephen Stamos (1985), "The Uneasy Calm: Third World Debt," Monthly Review, 36, March, 1-19.

Resnick, Stephen and Richard Wolff (eds.) (1985), Rethinking Marxism: Essays for Harry Magdoff and Paul Sweezy, Brooklyn, NY: Autonomedia.

Targ, Harry (1986), "Magdoff, Harry,” in Robert A. Gorman (ed.), Biographical Dictionary of Marxism, Westport, CO: Greenwood Press, 207-9.

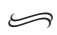

Since Western Europe went through a stage of feudalism before the stage of capitalism, and the stage of capitalism was to be the precursor of socialism, it was assumed by many followers of Marx that this progression was a necessary law of social development. It may be belaboring the obvious to emphasize here that such a concept is alien to scientific and, by the same token, to Marx's thinking. The hallmark of Marx's approach is the discovery of general truths about the specific changes that took place in the geographic areas and time periods he investigated, based on the evidence which was then available. From this, Marx distilled what he discovered to be the necessary interrelations-distinguishing between the primary and secondary elements-which explained the historical transformations of human societies. Acceptance of these generalizations as the most fruitful guide to explorations into questions of history and social science does not mean acceptance of a supra-historical design for all peoples, regardless of specific historical developments. Such acceptance would be mysticism, not science.

- Harry Magdoff, "The Achievement of Paul Baran," Monthly Review, March 1965 